\author{
Pathophysiology \\ of Haemostasis \\ and Thrombosis
}

\title{
Platelets and Anticoagulant Capacity in Patients with Inflammatory Bowel Disease
}

\author{
Torben Bjerregaard Larsen ${ }^{\mathrm{a}}$ J ens Nederby Nielsen ${ }^{\mathrm{b}}$ Lisbeth Fredholm ${ }^{\mathrm{b}}$ \\ Erik D. Lund ${ }^{\mathrm{b}}$ Ivan Brandslund ${ }^{\mathrm{b}}$ Pia Munkholm ${ }^{\mathrm{C}}$ Henrik Hey ${ }^{\mathrm{d}}$ \\ aDepartment of Clinical Biochemistry, Section for Thrombosis and Hemostasis, Aalborg Hospital, Aalborg, \\ bepartment of Clinical Biochemistry, Vejle County Central Hospital, Vejle, \\ 'Department of Medical Gastroenterology, University Hospital of Copenhagen, Copenhagen, and \\ dDepartment of Medical Gastroenterology, Vejle County Central Hospital, Vejle, Denmark
}

\section{Key Words}

Inflammatory bowel disease $\cdot$ Platelets $\cdot$ Thrombophilia . Coagulation $\cdot$ IL-6 ative colitis, but no association with the anticoagulant capacity could be demonstrated except for a decrease in protein $\mathrm{C}$ during high disease activity.

Copyright $\odot 2002$ S. Karger AG, Basel

\begin{abstract}
Patients with inflammatory bowel disease (IBD) are susceptible to thromboembolic complications. Several mechanisms can be responsible, including abnormal regulation of coagulation activity, disturbances of fibrinolysis, inflammatory reactions and thrombocytosis. The aim of this study was to assess hemostatic alterations in these parameters during exacerbation of disease. We studied disease activity in 99 IBD patients receiving anti-inflammatory therapy, in relation to: procoagulant markers, i.e. prothrombin fragment F1 +2 (F1 $+2)$, D-dimer and platelet count, anticoagulant markers, i.e. protein C, protein S and antithrombin, and a mediator of inflammation (IL-6). Coagulation activity and platelet count were increased during active disease in IBD patients compared with those in a state of remission. The IL-6 concentrations were positively correlated with disease activity and thrombocytosis in patients with ulcer-
\end{abstract}

\section{Background}

Patients with inflammatory bowel disease (IBD) are apparently more prone to thromboembolic complications earlier in life than non-IBD patients [1]. Several mechanisms can be responsible for this, including abnormal coagulation activity [2-6], disturbances of the fibrinolytic pathway [7] and thrombocytosis [8].

The coagulation system is a complex of several proand anticoagulant proteins which, in a subtle balance, ensures hemostasis and fibrinolysis in the human organism. The principal natural anticoagulant systems exert their effects through three primary mechanisms in the coagulant pathway. The tissue factor pathway inhibition (TFPI), the heparin-antithrombin complex and the protein C-thrombomodulin pathway, involving different anticoagulant proteins [9]. TFPI and antithrombin (AT) are

\begin{tabular}{ll}
\hline KARGER & ( ) 2002 S. Karger AG, Basel \\
Fax +4161306 1234 $34-8832 / 02 / 0322-0092 \$ 18.50 / 0$ \\
$\begin{array}{l}\text { E-Mail karger@karger.ch } \\
\text { www.karger.com }\end{array}$ & $\begin{array}{l}\text { Accessible online at: } \\
\text { www.karger.com/journals/pht }\end{array}$
\end{tabular}

Torben Bjerregaard Larsen, MD, PhD

Department of Clinical Biochemistry, Section for Thrombosis and Hemostasis

Aalborg Hospital, Hobrovej 18-22, PO Box 365

DK-9100 Aalborg (Denmark)

Tel. +45 9932 3180, Fax +459813 1196, E-Mail tblarsen@dadlnet.dk 
Table 1. Clinical characteristics of the included IBD patients

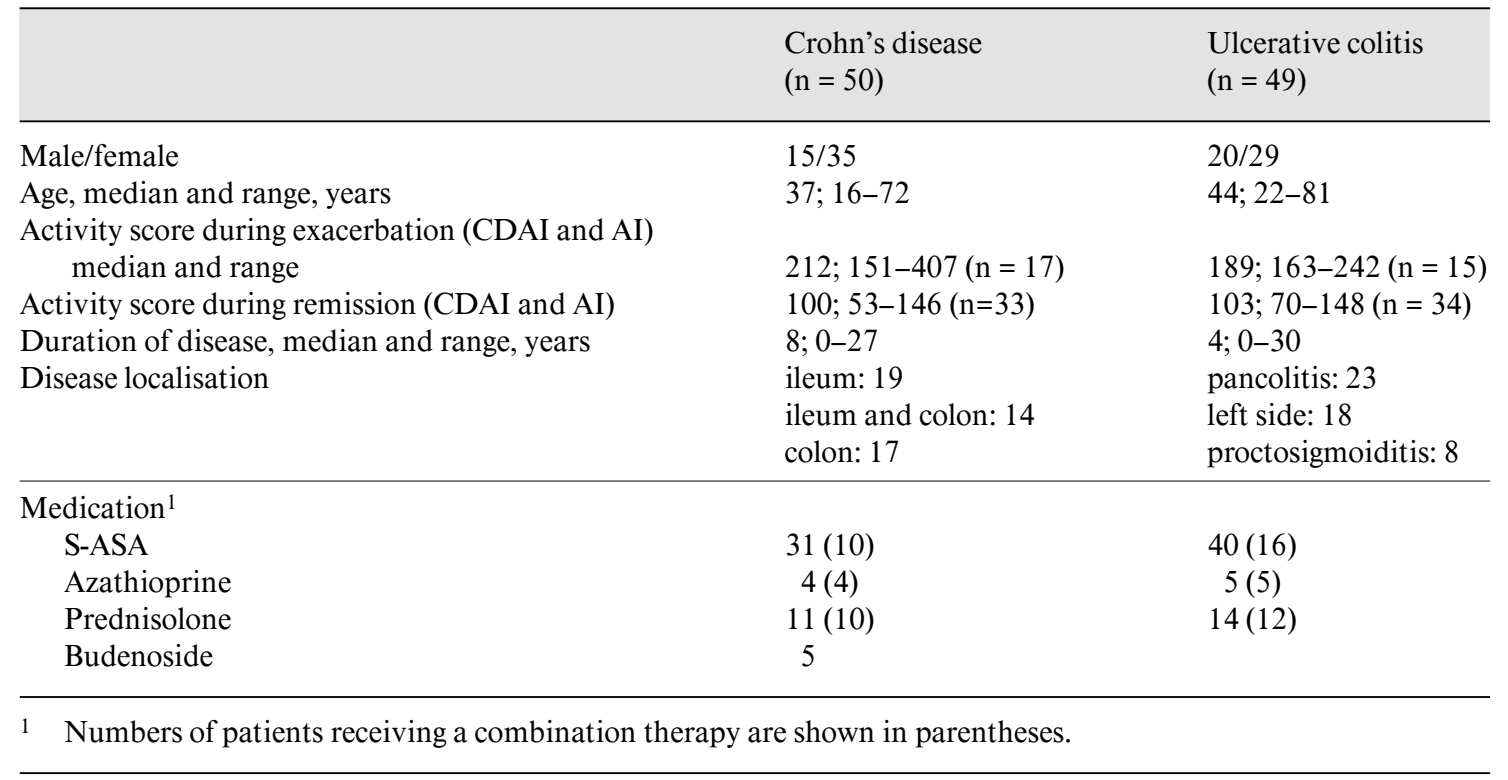

the major inhibitors of blood coagulation [10], and protein $\mathrm{C}$ is a vitamin-K-dependent plasma protein which is activated on the endothelium by the thrombin-trombomodulin complex [11]. Activated protein $C$ contributes to coagulation regulation through proteolytic cleavage and inactivation of coagulation factors Va and VIIIa, acting as a naturally occurring anticoagulant. This activity is dependent on protein $\mathrm{S}$ as a cofactor. Protein S either circulates freely or bound to $\mathrm{C} 4 \mathrm{~b}$-binding protein, but only free protein $\mathrm{S}$ possesses cofactor activity for protein $\mathrm{C}$ [12]. Deficiencies of either protein $\mathrm{C}$ or protein $\mathrm{S}$ are associated with increased thrombotic risk, and low levels of free protein $\mathrm{S}$ have been described previously in IBD patients [13]. AT mainly inhibits thrombin, but also exerts its action on activated coagulation factor $\mathrm{X}$.

Inflammatory reactions involving cytokines take place in patients with active IBD [8], and it has been demonstrated that interleukin-6 (IL-6), which is a mediator of inflammation, is associated with activation of the coagulation pathway [7]. IL-6 stimulates the release of thrombopoietin and induces thrombocytosis in patients with inflammatory disease [8], and reactive thrombocytosis is a typical feature in IBD [14]. Infusion of recombinant IL-6 stimulates coagulation activation [7] and is associated with a decreased capacity of the anticoagulant system in patients who suffered an acute stroke [15].

Under normal circumstances, the coagulation system is balanced in favour of anticoagulation. An impairment of the natural anticoagulant system and an increased platelet concentration in blood might contribute to the earlier occurrence of thromboembolic complications in patients with IBD. Whether these thromboembolic complications are associated with increased coagulation activity during active disease in patients receiving anti-inflammatory therapy is not known. The aim of this study was to elucidate whether these patients have alterations in procoagulant markers in the anticoagulation system and in platelet count, during disease exacerbation.

\section{Materials and Methods}

This study has been approved by the regional ethical committee of the counties of Vejle and Funen, according to Danish law. Informed consent was obtained from all participants.

\section{IBD Cases}

The study was designed as a cross-sectional study comprising IBD patients receiving anti-inflammatory therapy. Patients from the outpatients clinic of Vejle County Hospital and Hvidovre University Hospital of Copenhagen were consecutively included. Patients who fulfilled the international diagnostic criteria of IBD were investigated and disease activity was determined in the individual patient (clinical characteristics and medication in table 1). We employed the most frequently used indices for disease activity characterization: Crohn's Disease Activity Index (CDAI) and Activity Index (AI) for ulcerative colitis (UC) (values less than 150 are considered a state of remission in both diseases) [16]. Patients with hepatic disease, infection, previous thrombosis, other chronic inflammatory disease and pregnancy 
Table 2. IL-6 and pro- and anticoagulant markers in relation to disease activity ${ }^{1}$

\begin{tabular}{|c|c|c|c|c|c|c|c|}
\hline & \multicolumn{3}{|l|}{ Crohn's disease } & \multicolumn{3}{|c|}{ Ulcerative colitis } & \multirow{2}{*}{$\begin{array}{l}\text { Reference } \\
\text { value }^{2}\end{array}$} \\
\hline & active disease $^{3}$ & remission & $\mathrm{p}$ & active disease & remission & $\mathrm{p}$ & \\
\hline IL-6, $\mu \mathrm{g} / 1$ & $1.9(0.3-21.6)$ & $1.2(0.2-10.6)$ & $<0.02$ & $3.5(0.1-74.9)$ & $1.0(0.1-5.1)$ & $<0.01$ & $<3.1$ \\
\hline \multicolumn{8}{|c|}{ Procoagulant activity } \\
\hline $\mathrm{F} 1+2, \mathrm{nmol} / 1$ & $1.8(1.1-3.5)$ & $1.5(0.6-4.7)$ & 0.08 & $2.3(0.4-6.9)$ & $1.7(0.8-2.5)$ & $<0.01$ & $0.6-2.4$ \\
\hline High D-dimer ${ }^{4}$ & $62.5 \%$ & $37.5 \%$ & 0.7 & $68.0 \%$ & $36 \%$ & 0.3 & $<0.05 \mathrm{mg} / 1$ \\
\hline \multicolumn{8}{|c|}{ Natural anticoagulants, $k U / l$} \\
\hline Antithrombin & $1.0(0.8-1.2)$ & $1.0(0.7-1.2)$ & 0.4 & $1.0(0.8-1.4)$ & $1.0(0.8-1.3)$ & 0.7 & $0.6-1.3$ \\
\hline Total protein $\mathrm{S}$ & $1.1(0.7-1.7)$ & $1.1(0.6-1.4)$ & 0.8 & $1.2(0.7-1.6)$ & $1.1(0.7-1.6)$ & 0.6 & $0.7-1.3$ \\
\hline Free protein $S$ & $0.3(0.2-0.4)$ & $0.3(0.2-0.5)$ & 0.16 & $0.3(0.1-0.5)$ & $0.4(0.2-0.6)$ & 0.07 & $0.2-0.5$ \\
\hline Protein $\mathrm{C}$ & $1.2(0.9-1.6)$ & $1.1(0.8-2.0)$ & 0.7 & $1.3(0.9-1.6)$ & $1.2(0.9-1.9)$ & 0.4 & $0.8-1.2$ \\
\hline Platelets, $10^{9} / 1$ & $288(156-556)$ & $270(174-487)$ & 0.7 & $369(158-547)$ & $266(101-440)$ & $<0.01$ & $140-340$ \\
\hline \multirow{2}{*}{\multicolumn{8}{|c|}{$\begin{array}{l}1 \text { Median; ranges are shown in parentheses. } \\
2 \text { Reference values based on } 31 \text { healthy persons ( } 21 \text { females and } 10 \text { males): median age and range, respectively: } 38 \text { (22-53) and } 37.5 \\
(24-48) \text { vears. }\end{array}$}} \\
\hline & & & & & & & \\
\hline \multicolumn{8}{|c|}{$\begin{array}{l}(24-48) \text { years. } \\
3 \\
\text { Disease activity index }>150\end{array}$} \\
\hline $4>0.50 \mathrm{mg} / \mathrm{l}$. & & & & & & & \\
\hline
\end{tabular}

were excluded from the study. We studied disease activity in relation to: procoagulant markers [prothrombin fragment $\mathrm{F} 1+2(\mathrm{~F} 1+2)$, D-dimer and platelet count], anticoagulant markers (protein C, protein S and antithrombin), and IL-6 as a mediator of inflammation.

\section{Assays for Blood Coagulation and IL-6}

Blood was collected in $1 / 10$ volume of $0.13 \mathrm{~mol} / \mathrm{l}$ sodium citrate and centrifuged in two steps at $3,000 \mathrm{~g}$ for $10 \mathrm{~min}$ to obtain plateletpoor plasma, which was stored at $-80^{\circ} \mathrm{C}$ until analysis. Plasma was collected and processed by the same laboratory technician, who was unaware of the clinical conditions of the patients investigated. The analysis of F1 +2 was performed using an enzyme immunoassay utilizing an ELISA-based method with polyclonal antibodies (Dade Behring ${ }^{\circledR}$ ) and D-dimer was measured using the Tinaquant D-dimer assay (Roche Diagnostics). AT and protein $\mathrm{C}$ activities were measured by chromogenic methods (Chromogenix). Free and total protein $\mathrm{S}$ antigens were determined by an immunological assay (Diagnostica Stago).

Plasma IL-6 was determined using a quantitative sandwich enzyme-linked immunoadsorbent assay (Quantikine) kit obtained from R\&D Systems (Minneapolis, Minn., USA).

All tests were handled according to the manufacturers' instructions. A healthy control group of 21 women and 10 men was recruited among the laboratory staff, and reference values were calculated (mean \pm 2 standard deviations).

\section{Statistics}

Comparisons of continuous variables were conducted using t test statistics or Mann-Whitney's test when appropriate (inhomogeneity of the variances). Fisher's exact test was used for comparison of proportions.

\section{Results}

Initially, 106 patients with IBD were examined, but 7 patients -3 and 4 with UC and Crohn's disease (CD), respectively - met a criterion for exclusion, leaving a total of 99 patients included (49 and 50 with UC and CD, respectively).

In patients with IBD, the coagulation activity was significantly increased during active disease compared with a state of remission. In UC patients, the median F1 +2 was 2.3 and $1.7 \mathrm{nmol} / 1(\mathrm{p}<0.01)$ and $\mathrm{D}$-dimer $>0.50 \mathrm{mg} / \mathrm{l}$ was 62.5 and $37.5 \%(p=0.045)$ during high and low disease activity, respectively. In CD patients, the median $\mathrm{F} 1+2$ was 1.8 and $1.5 \mathrm{nmol} / \mathrm{l}(\mathrm{p}=0.08)$ and $\mathrm{D}$-dimer $>0.50 \mathrm{mg} / \mathrm{l}$ was 68 and $36 \%(\mathrm{p}<0.01)$ during high and low disease activity, respectively (table 2).

The activities or concentrations of the natural anticoagulants (AT, protein C and protein S) were not decreased as a consequence of alterations in disease activity except for a lower protein $\mathrm{C}$ activity in UC patients with high $(>3.1$ $\mu \mathrm{g} / \mathrm{l}) \mathrm{IL}-6$ concentrations ( 1.2 and $1.1 \mathrm{kU} / \mathrm{l}$ at high and normal IL-6 concentrations, respectively, $p=0.02$ ) (table 3 ).

In patients with UC, the median platelet count was increased to $369 \times 10^{9} / 1$ during active disease compared to $266 \times 10^{9} / 1$ in remission $(\mathrm{p}<0.01)$. In $\mathrm{CD}$, the median platelet count in active disease and in remission was 288 and $270 \times 10^{9} / 1$, respectively (not statistically different).
Larsen/Nielsen/Fredholm/Lund/ Brandslund/Munkholm/Hey 
Table 3. Disease activity and pro- and anticoagulant markers in relation to IL-6 ${ }^{1}$

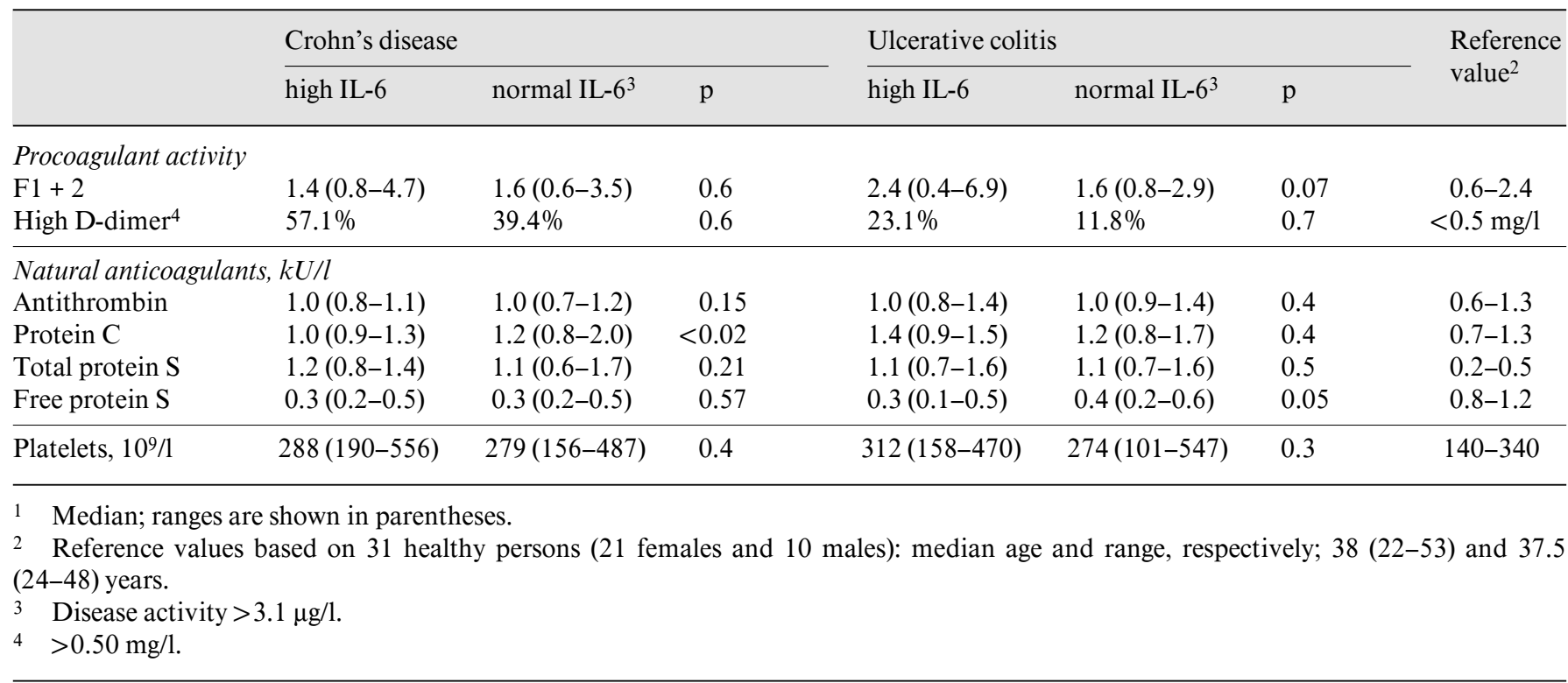

Both values were within the reference range for platelet count.

The IL-6 concentrations were positively associated with disease activity and platelet count (table 2), but no association was found with alterations in the natural anticoagulants for this mediator of inflammation (table 3).

\section{Discussion}

A relative hypercoagulable state is present in patients with IBD $[1,4]$. The difference in disease activity between patients in exacerbation and patients in a state of remission was too low (possibly due to good treatment) to elicit clearer differences in both pro- and anticoagulant activity. This also fits with the relatively low IL-6 activities given. A larger difference of IL- 6 between exacerbation and remission in UC did not parallel differences in CDAI and AI scores, respectively, and cannot explain why coagulation activity differs less in CD than in UC. One explanation could be the invasive nature of $\mathrm{CD}$ and the release of increased amounts of tissue factor. An increased procoagulant activity, measured by $\mathrm{F} 1+2$, is seen during active disease, but the mean values of F1 +2 in high and low disease activity are still within the normal range and are probably clinically irrelevant. The lower concentration of protein $\mathrm{C}$ in CD patients with high IL-6 concentrations is interesting, but the lower concentration is within the normal range and probably has no clinical implications.

Vila et al. [15] demonstrated that in patients with acute stroke higher levels of IL-6 were associated with severer neurologic deficits on admission, greater infarct size, higher levels of acute-phase reactants and lower levels of free protein S. In the present study, higher IL-6 levels were not associated with a similar imbalance in favour of a higher coagulation activity or an impaired anticoagulant system, but higher IL-6 levels were significantly associated with higher disease activity (table 2). It is possible that IL-6 suppresses free protein $\mathrm{S}$ in untreated patients, but this effect is insignificant when patients are under antiinflammatory therapy as the patients in the present study. It is conceivable that anti-inflammatory drugs are able to modulate the anticoagulant response in IBD, perhaps by altered cytokine release from monocytes. Higher IL-6 levels in IBD are preceded by an increase in tumour necrosis factor-alpha (TNF- $\alpha$ ), and it has recently been demonstrated that heparin attenuates the TNF- $\alpha$ induced inflammatory response (reduction of leucocyte recruitment) in a rodent model [17], supporting the assumption that inflammatory mechanisms in IBD are related to the presence of high IL-6 levels. This action of heparin was not dependent on its anticoagulant properties, as even small doses of heparin were sufficient to inhibit the inflammatory response to TNF- $\alpha$. 
An elevated platelet count is a frequent finding in IBD, and recent work indicates that platelets exhibit several proinflammatory properties [18], increasing the risk of thromboembolic complications in these patients. On the other hand, aminosalicylates reduce platelet activity, and it has been demonstrated that 5-aminosalicylic acid (5ASA) inhibits platelet activation [19], contributing to the beneficial action of 5-ASA in inflammatory bowel disease. Whether anti-inflammatory therapy in sufficient to prevent systemic or microvascular thrombosis in IBD, or whether the use of specific antiplatelet drugs will provide new therapeutic possibilities, remains to be established. The increase in platelet count during high disease activity was only evident in UC patients, but the significance of this is uncertain.

Our study has strengths and limitations. In this study it was possible to make a direct comparison of several factors affecting the risk of thrombosis: the procoagulant markers, the anticoagulation system, platelet count and inflammatory response, during exacerbation of disease. Other studies have investigated these factors, often separately, and two of the studies included only 12 and 16 patients, respectively $[2,5]$. In spite of the fact that the present study is one of the major studies on coagulation and IBD, it did not have enough statistical power to investigate a correlation between medication and coagulant activity, and no hard endpoints (e.g. thrombosis) were included in the study.

In conclusion, higher coagulation activity is present during high disease activity in IBD patients receiving anti-inflammatory therapy. The difference in disease activity was too low to elicit clearer differences in both proand anticoagulant activities, but the increase in coagulation activity could be caused by higher inflammatory activity. UC patients with exacerbation of disease had relative thrombocytosis, despite anti-inflammatory therapy, but the clinical significance of this remains to be established.

\section{Acknowledgements}

This work was supported by the Health Insurance Foundation 'danmark' and Udviklingsraadet, Vejle County Hospital.

\section{References}

1 Grip O, Svensson PJ, Lindgren S: Inflammatory bowel disease promotes venous thrombosis earlier in life. Scand J Gastroenterol 2000;35: 619-623.

2 Lake AM, Stauffer JQ, Stuart MJ: Hemostatic alterations in inflammatory bowel disease: Response to therapy. Am J Dig Dis 1978;23:897902.

3 Edwards RL, Levine JB, Green R, Duffy M, Mathews E, Brande W, Rickles FR: Activation of blood coagulation in Crohn's disease. Increased plasma fibrinopeptide A levels and enhanced generation of monocyte tissue factor activity. Gastroenterology 1987;92:329-337.

4 Kjeldsen J, Lassen JF, Brandslund I, Schaffalitzky de Muckadell OB: Markers of coagulation and fibrinolysis as measures of disease activity in inflammatory bowel disease. Scand J Gastroenterol 1998;33:637-643.

5 Hudson M, Hutton RA, Wakefield AJ, Sawyerr AM, Pounder RE: Evidence for activation of coagulation in Crohn's disease. Blood Coagul Fibrinolysis 1992;3:773-778.

6 Souto JC, Martinez E, Roca M, Mateo J, Pujol J, Gonzalez D, Fontcuberta J: Prothrombotic state and signs of endothelial lesion in plasma of patients with inflammatory bowel disease. Dig Dis Sci 1995;40:1883-1889.
7 Stouthard JM, Levi M, Hack CE, Veenhof CH, Romijn HA, Sauerwein HP, Van der Poll T: Interleukin-6 stimulates coagulation, not fibrinolysis, in humans. Thromb Haemost 1996;76: 738-742.

8 Heits F, Stahl M, Ludwig D, Stange EF, Jelkmann W: Elevated serum thrombopoietin and interleukin- 6 concentrations in thrombocytosis associated with inflammatory bowel disease. J Interferon Cytokine Res 1999;19:757-760.

9 Rosendaal FR: Venous thrombosis: A multicausal disease. Lancet 1999;353:1167-1173.

10 van Boven HH, Olds RJ, Thein SL, Reitsma PH, Lane DA, Briet E, Vandenbroucke JP, Rosendaal FR: Hereditary antithrombin deficiency. Heterogeneity of the molecular basis and mortality in Dutch families. Blood 1994; 84:4209-4213.

11 Esmon CT: The roles of protein C and thrombomodulin in the regulation of blood coagulation. J Biol Chem 1989;264:4743-4746.

12 Dahlbäck B: Protein S and C4b-binding protein: Components involved in the regulation of the protein $\mathrm{C}$ anticoagulant system. Thromb Haemost 1991;66:49-61.
13 Koutroubakis IE, Sfiridaki A, Mouzas IA, Maladaki A, Kapsoritakis A, Roussomoustakaki M, Kouroumakis EA, Manousos ON: Resistance to activated protein $\mathrm{C}$ and low levels of free protein $\mathrm{S}$ in Greek patients with inflammatory bowel disease. Am J Gastroenterol 2000; 95:190-194.

14 Santhosh-Kumar CR, Yohannan MD, Higgy KE, al Mashhadani SA: Thrombocytosis in adults. Analysis of 777 patients. J Intern Med 1991;229:493-495.

15 Vila N, Reverter JC, Yague J, Chamorro A: Interaction between interleukin- 6 and the natural anticoagulant system in acute stroke. J Interferon Cytokine Res 2000;20:325-329.

16 Singleton JW: Clinical activity assessment in inflammatory bowel disease. Dig Dis Sci 1987; 32:42S-45S.

17 Salas A, Sans M, Soriano A, Reverter JC, Anderson DC, Pique JM, Panes J: Heparin attenuates TNF-alpha induced inflammatory response through a CD11b dependent mechanism. Gut 2000;47:88-96.

18 Collins CE, Rampton DS: Review article: Platelets in inflammatory bowel disease pathogenetic role and therapeutic implications. Aliment Pharmacol Ther 1997;11:237-247.

19 Carty E, MacEy M, Rampton DS: Inhibition of platelet activation by 5 -aminosalicylic acid in inflammatory bowel disease. Aliment Pharmacol Ther 2000; 14:1169-1179.

Larsen/Nielsen/Fredholm/Lund/

Brandslund/Munkholm/Hey 